\title{
Epidemiologia gruźlicy w województwie wielkopolskim i system nadzoru
}

\section{Epidemiology of tuberculosis in Greater Poland Province and the system of supervision}

\author{
Beata Marciniak, Andrzej Trybusz ${ }^{1}$
}

Poznań

\begin{abstract}
Streszczenie: Gruźlica jest ciagle istotnym problemem epidemiologicznym, medycznym i społecznym współczesnego świata. Według Światowej Organizacji Zdrowia, w 2016 r. zachorowało na nią około 10,4 mln osób. W 30 krajach Unii Europejskiej i Europejskiego Obszaru Gospodarczego odnotowano prawie 59 tys. zachorowań, największa grupę stanowili chorzy z Polski, Rumunii i Wielkiej Brytanii (45\% ogółu przypadków). W Polsce prawie wszystkie zachorowania to przypadki rodzime, zauważalna jest jednak tendencja wzrostu liczby zachorowań u imigrantów. W wielu krajach europejskich przypadki gruźlicy odnotowuje się najczęściej wśród imigrantów, np. w Szwecji 89,8\%, co wskazuje, iż podejmując działania $\mathrm{p} /$ epidemiczne należy $\mathrm{i}$ ten aspekt wziąć pod uwage $\mathrm{w}$ analizach czynników wpływających na rozprzestrzenianie się gruźlicy w Polsce. Choć liczba zarejestrowanych zachorowań zarówno w Polsce, jak i w województwie wielkopolskim, z roku na rok maleje, co jest niewatpliwie efektem prowadzonego od wielu lat nadzoru epidemiologicznego, jest to nadal choroba zakaźna, która wymaga stałego monitorowania.
\end{abstract}

\begin{abstract}
Tuberculosis is still important epidemiologic, medical and social problem of the contemporary world. According to WHO, in $2016 \mathrm{~TB}$ has infected about 10.4 million people worldwide. In thirty member states of the European Union and the European Economic Area about 59000 new cases were reported, the majority of them in Poland, Romania and the United Kingdom (45\% of all cases). In Poland almost all new infections are indigenous cases, however, the trend of increasing number of TB infections among immigrants is noticed. In numerous European states TB cases are reported mostly among immigrants, for instance in Sweden $89,8 \%$ of all cases, this aspect should be considered in the analyses of the factors affecting the spread of tuberculosis in Poland. Despite a number of registered TB cases in Poland, and Greater Poland Province as well, decreases year by year, which is obviously a result of the system of supervision, tuberculosis is still infectious disease which requires constant monitoring.
\end{abstract}

Słowa kluczowe: gruźlica, dane epidemiologiczne, system nadzoru.

Keywords: tuberculosis, epidemiological data, system of supervision

1 Wojewódzka Stacja Sanitarno-Epidemiologiczna w Poznaniu. Artykuł stanowi recenzowaną wersje wykładu wygłoszonego 19 maja 2018 r. w Wolsztynie podczas konferencji pt. „Gruźlica - dawne doświadczenia, obecne osiagnięcia i zagrożenia". 


\section{System nadzoru nad gruźlicą w Polsce}

Aktualnie prowadzony w Polsce system nadzoru nad osobami podejrzanymi o zachorowanie oraz chorymi na gruźlicę, jak również osobami z kontaktu z chorym na gruźlicę, wynika z Ustawy o zapobieganiu oraz zwalczaniu zakażeń i chorób zakaźnych u ludzi z dnia 5 grudnia 2008 r. (Dz. U. z 2018 r. poz. 151), obowiązującej od 1 stycznia $2009 \mathrm{r}$. Zgodnie z powyższą ustawą lekarz lub felczer, który podejrzewa lub rozpoznaje gruźlice jest obowiązany do zgłoszenia tego faktu państwowemu powiatowemu inspektorowi sanitarnemu albo państwowemu granicznemu inspektorowi sanitarnemu właściwemu dla miejsca rozpoznania choroby zakaźnej. Zgłoszenie dokonuje się niezwłocznie, nie później jednak niż w ciagu 24 godzin od chwili powzięcia podejrzenia lub rozpoznania zachorowania. Wzór zgłoszenia oraz sposób jego przekazania do organów inspekcji sanitarnej określaja przepisy wykonawcze, jest nim Rozporządzenie Ministra Zdrowia w sprawie zgłoszeń podejrzenia lub rozpoznania zakażenia, choroby zakaźnej lub zgonu z powodu zakażenia lub choroby zakaźnej z dnia 10 lipca 2013 r. (Dz. U. z 2013 r. poz. 848). Państwowy Powiatowy Inspektor Sanitarny po otrzymaniu zgłoszenia analizuje dokumentację, a w przypadku chorych na gruźlicę płuc w okresie prątkowania ustala również osoby ze styczności z chorym, które podlegają nadzorowi epidemiologicznemu. Dane o zachorowaniach w poszczególnych powiatach przekazywane sa do wojewódzkich stacji sanitarno-epidemiologicznych, a następnie do Instytutu Gruźlicy i Chorób Płuc w Warszawie. Instytut prowadzi Krajowy Rejestr Zachorowań na gruźlicę od 1957 roku. Instytut Gruźlicy i Chorób Płuc, na mocy decyzji Głównego Inspektora Sanitarnego z dnia 3 września 2009 roku jest krajowa specjalistyczna jednostką właściwą w zakresie gruźlicy. Przygotowuje raporty o zachorowaniach na gruźlice w Polsce, wykonuje analizy bieżącej sytuacji epidemiologicznej gruźlicy w kraju i jej zmian zachodzacych w czasie. Instytut należy do międzynarodowego systemu nadzoru nad gruźlica, przekazuje dane o zapadalności na gruźlice w Polsce do Europejskiego Centrum do Spraw Zapobiegania i Kontroli Chorób (ECDC) oraz Światowej Organizacji Zdrowia (WHO), które prowadzą nadzór nad tą chorobą w Europie i świecie.

\section{Historia nadzoru epidemiologicznego nad gruźlicą}

W latach 2001-2008 nadzór nad gruźlica regulowała Ustawa o chorobach zakaźnych i zakażeniach z dnia 6 września 2001 r. (Dz. U. Nr 126,poz. 1384), zgodnie z która podejrzenia lub rozpoznania zachorowania na gruźlicę lekarz lub felczer miał obowiązek zgłaszać właściwemu ze względu na miejsce zachorowania wojewódzkiemu inspektorowi sanitarnemu lub wskazanej przez niego specjalistycznej jednostce właściwej w zakresie gruźlicy i chorób płuc. Nadzór nad zachorowaniami w poszczególnych województwach prowadzony był wówczas przez jednostki specjalistyczne, które $\mathrm{w}$ ramach umów zawartych $\mathrm{z}$ wojewódzkimi inspektorami sanitarnymi gromadziły, weryfikowały oraz prowadziły analizy i upowszechniały informacje o zachorowaniach na gruźlicę $\mathrm{w}$ danym regionie. Ustawa ta nie regulowała natomiast prowadzenia nadzoru epidemiologicznego nad osobami z kontaktu, co szczegółowo zostało 
ujęte w zmieniającej ją Ustawie o zapobieganiu oraz zwalczaniu zakażeń i chorób zakaźnych u ludzi z dnia 5 grudnia 2008 r. (Dz.U. z 2018 r. poz. 151).

\section{System nadzoru nad gruźlicą w Wielkopolsce}

Do 2006 roku w województwie wielkopolskim jednostką specjalistyczną w zakresie nadzoru nad gruźlicą było Wielkopolskie Centrum Chorób Płuc i Gruźlicy w Poznaniu. Z uwagi na zgłaszane przez Instytut Gruźlicy i Chorób Płuc w Warszawie uwagi dotyczące prawdopodobnego niedoszacowania zachorowań w województwie, Państwowy Wojewódzki Inspektor Sanitarny w Poznaniu, mając na uwadze poprawę systemu zgłaszania, rejestracji i nadzoru nad gruźlica, od grudnia 2006 obowiązki dotyczace wydawania decyzji administracyjnych oraz podejmowania czynności w celu zapobiegania szerzeniu się gruźlicy w poszczególnych powiatach powierzył państwowym powiatowym inspektorom sanitarnym. Wprowadzono również w ramach powierzonych obowiązków nadzór nad osobami z kontaktu z chorymi na gruźlicę prątkująca. Rejestrację i analizę danych epidemiologicznych na podstawie przysyłanych formularzy zgłoszeń zachorowań od 2007 roku prowadzi Oddział Epidemiologii Wojewódzkiej Stacji Sanitarno-Epidemiologicznej w Poznaniu. Inspekcja sanitarna województwo wielkopolskiego jako pierwsza w Polsce podjęła działania aktywnego nadzoru nad gruźlica. Wprowadzone zasady znaczaco wpłynęły na doszacowanie i uszczegółowienie systemu rejestracji zachorowań (wzrost zachorowań z 371 w 2006 r. do 528 w 2007 r. i 562 w 2008 r.), a prowadzony nadzór nad osobami chorymi oraz osobami z kontaktu przez powiatowe stacje sanitarno-epidemiologiczne wpłynął na spadek liczby zachorowań w następnych latach.

\section{Epidemiologia gruźlicy}

Sytuacja epidemiologiczna gruźlicy oceniana jest poprzez takie jej wskaźniki jak: zapadalność ${ }^{2}$ ogólna oraz w grupach w zależności od wieku i płci, udział nowych zachorowań i wznów oraz gruźlicy płuc i pozapłucnej, zapadalność na gruźlicę z potwierdzeniem bakteriologicznym (definitywne rozpoznanie choroby), zapadalność na gruźlice płuc z dodatnim wynikiem badania bakteriologicznego plwociny, odsetek cudzoziemców i więźniów wśród ogółu chorych, współwystępowanie gruźlicy i HIV, rozpowszechnienie gruźlicy wywołanej przez pratki oporne na leki i umieralność z powodu gruźlicy. Szczegółowe dane dotyczące powyższych wskaźników za dany rok kalendarzowy publikowane są przez Instytut Gruźlicy i Chorób Płuc w Warszawie w Biuletynie „Gruźlica i Choroby Układu Oddechowego w roku...”.

W kolejnych latach ostatniego pięciolecia (2013-2017) zmiany zapadalności dla Polski wynosiły: (-)4,1\%, (-)7,4\%, (-)4,0\%, +0,6\%, (-)10,1\%. Średni roczny spadek zapadalności w ocenianym pięcioleciu wynosi (-)4,2\% i był wyższy niż w pięcioleciu wcześniejszym, w którym wynosił (-)1,2\%.

2 Zapadalność - liczba zachorowań w określonym czasie w stosunku do liczby ludności narażonej. 
Tabela 1. Sytuacja epidemiologiczna gruźlicy w Polsce i województwie wielkopolskim latach 2013-2017

\begin{tabular}{|c|c|c|c|c|}
\hline \multirow{2}{*}{ Lata } & \multicolumn{2}{|c|}{ Województwo wielkopolskie } & \multicolumn{2}{c|}{ Polska } \\
\cline { 2 - 5 } & $\begin{array}{c}\text { Liczba } \\
\text { zachorowań }\end{array}$ & Zapadalność & $\begin{array}{c}\text { Liczba } \\
\text { zachorowań }\end{array}$ & Zapadalność \\
\hline 2013 & 343 & 9,9 & 7250 & 18,8 \\
\hline 2014 & 321 & 9,3 & 6698 & 17,4 \\
\hline 2015 & 289 & 8,3 & 6430 & 16,7 \\
\hline 2016 & 281 & 8,1 & 6444 & 16,8 \\
\hline 2017 & 311 & 8,9 & 5787 & 15,1 \\
\hline
\end{tabular}

Dane liczbowe oraz zapadalność na 100 tys. ludności

W analogicznym okresie w Wielkopolsce zapadalność kształtowała się: (-)9,2\%, $(-) 6,06 \%,(-) 10,8 \%,(-) 2,4 \%,+9,9 \%$.

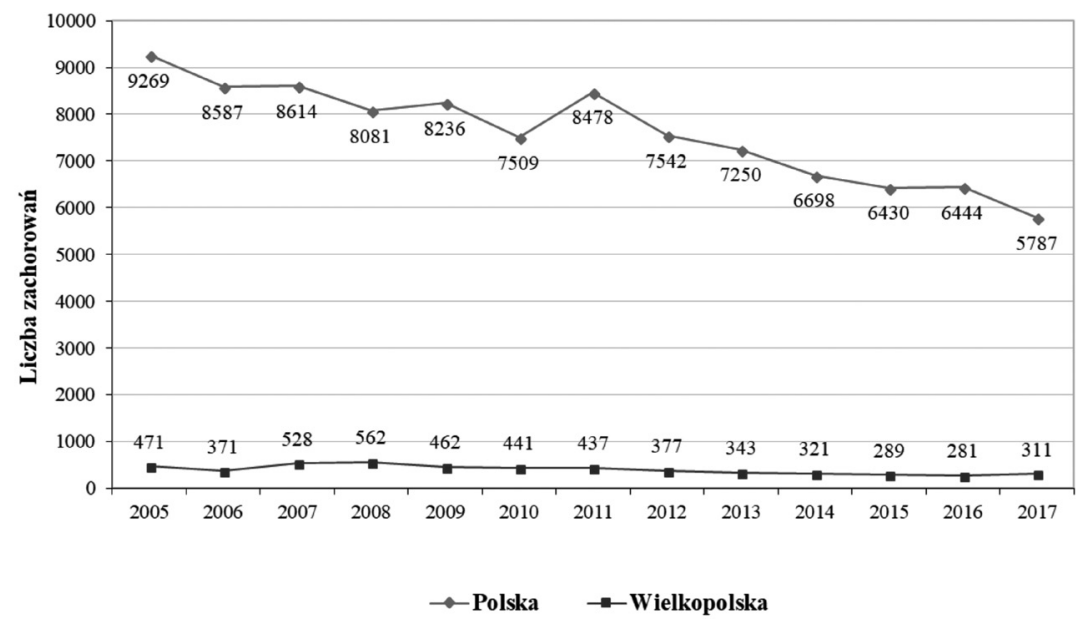

Ryc. 1. Liczba zachorowań na gruźlicę w Polsce i Wielkopolsce w latach 2005-2017 (dane liczbowe)

W Polsce w 2017 roku zarejestrowano 5787 zachorowań na gruźlicę, czyli 657 przypadków mniej niż w roku poprzednim i 2827 przypadków mniej w porównaniu z rokiem 2007.

W Wielkopolsce w 2017 roku zarejestrowano 311 zachorowań na gruźlicę, czyli o 30 przypadków więcej niż w roku poprzednim i 217 przypadków mniej niż 10 lat temu (2007 r.). 


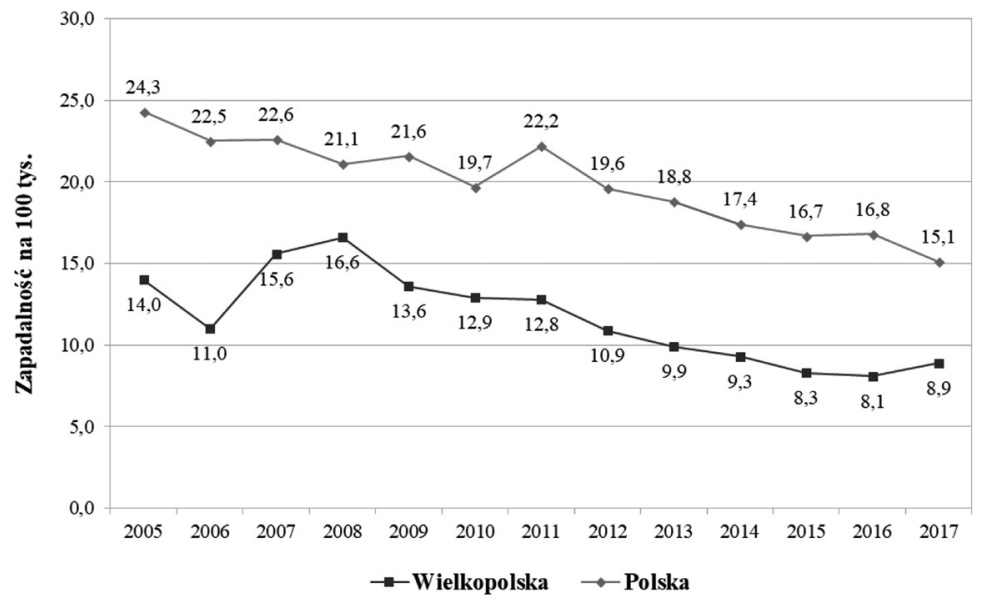

Ryc. 2. Zapadalność na gruźlicę w Polsce i Wielkopolsce w latach 2005-2017 (zapadalność na 100 tys. ludności)

W Polsce zapadalność na gruźlicę wszystkich postaci w 2017 roku wynosiła 15,1 i była mniejsza o 10,1\% w porównaniu z rokiem 2016 oraz o 33,2\% w porównaniu z rokiem 2007, w którym wynosiła 22,6.

W Wielkopolsce zapadalność na gruźlicę wszystkich postaci w 2017 roku wynosiła 8,9 i była większa o 9,9\% w porównaniu z rokiem 2016 oraz niższa o 42,9\% w porównaniu z rokiem 2007, w którym wynosiła 15,6.

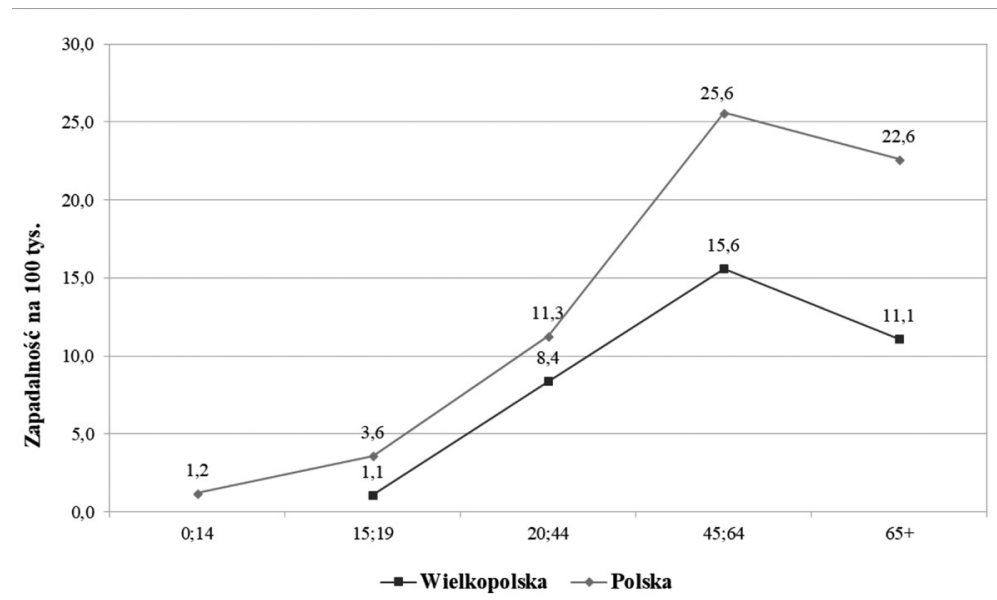

Ryc. 3. Zapadalność na gruźlicę wszystkich postaci w Polsce i Wielkopolsce wg grup wiekowych w roku 2017 (zapadalność na 100 tys. ludności)

W 2017 r. zarówno w Polsce jak i w Wielkopolsce współczynnik zapadalności na gruźlicę był tym wyższy, im starsza była grupa wiekowa, ale tylko do wieku 45-64 lata. 
W Polsce współczynniki wynosiły od 1,2 wśród dzieci do 14 roku życia do 25,6 u osób w wieku 45 do 64 lat. W Wielkopolsce nie zarejestrowano zachorowań w najmłodszej grupie, wśród młodzieży odnotowano 2 przypadki (zapadalność 1,1), najliczniejsza grupę również stanowiły osoby w wieku 45-64 lata (zapadalność 15,6). Chorzy w grupie 45-64 lata stanowili w Polsce 44,9\% ogółu chorych, bardzo podobnie jak w Wielkopolsce $-44,7 \%$.

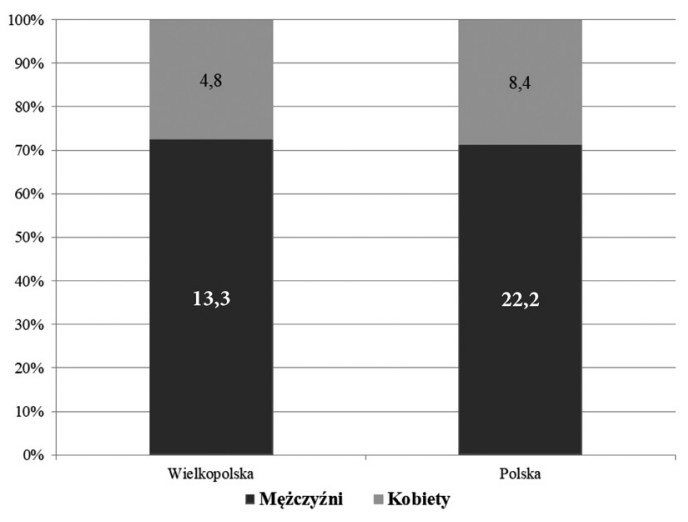

Ryc. 4. Zapadalność na gruźlicę wszystkich postaci w Polsce i Wielkopolsce wg płci w roku 2017 (zapadalność na 100 tys. ludności)

Podobnie jak w latach poprzednich, zapadalność na gruźlicę wśród mężczyzn była ponad dwukrotnie wyższa niż u kobiet. W 2017 r. w Polsce zarejestrowano 4126 chorych mężczyzn (zapadalność 22,2), w Wielkopolsce - 225 (zapadalność 13,3). Przypadki gruźlicy u mężczyzn stanowiły 71,3\% ogółu zachorowań w Polsce, podobnie jak w województwie wielkopolskim 72,3\%. Odsetek zachorowań w grupie kobiet w Polsce wynosił 28,7\% (1666 zachorowania), w Wielkopolsce 27,6\% (86 zachorowań).

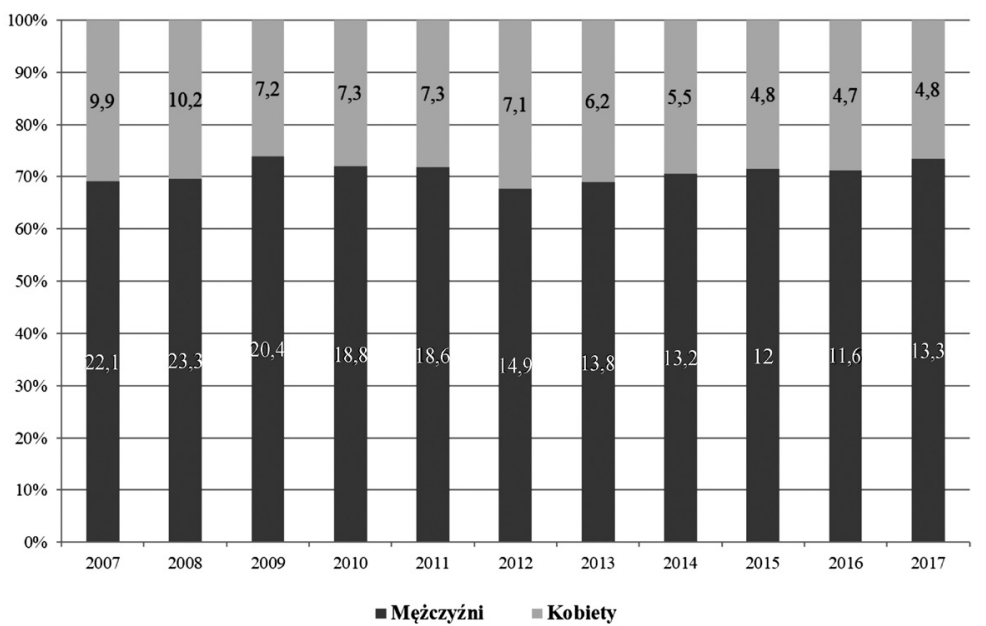

Ryc. 5. Liczba zachorowań na gruźlicę wszystkich postaci wg płci w Wielkopolsce w latach 2007-2017 (dane liczbowe) 
Sytuacja zachorowań na gruźlicę w Wielkopolsce w grupie kobiet i mężczyzn na przestrzeni ponad 10 lat jest korzystna, wykazuje tendencję spadkowa. Jedynie w 2017 r. odnotowano o 28 przypadków wzrost zachorowań w grupie mężczyzn i o 2 przypadki w grupie kobiet.

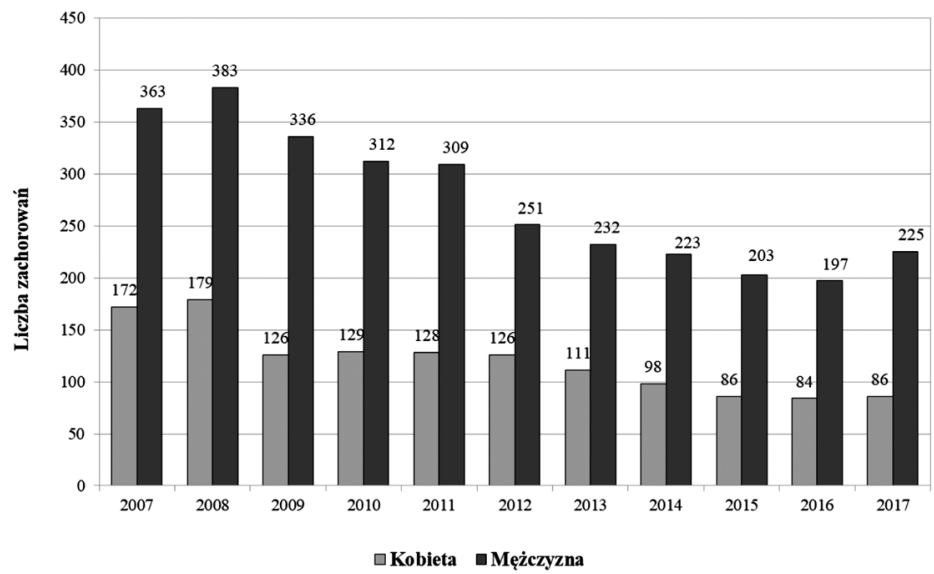

Ryc. 6. Zapadalność na gruźlicę wszystkich postaci wg płci w Wielkopolsce w latach 2007-2017 (zapadalność na 100 tys. ludności)

Zapadalność na gruźlice w Wielkopolsce w grupie mężczyzn i kobiet na przestrzeni kilkunastu lat rokrocznie się zmniejszała. Mężczyźni stanowili około 70\% grupę wszystkich rejestrowanych $\mathrm{w}$ województwie zachorowań. Niewielki wzrost zapadalności w porównaniu do roku poprzedniego odnotowano jednych w roku 2017 o 14,7\% u mężczyzn i o 2,2\% u kobiet.

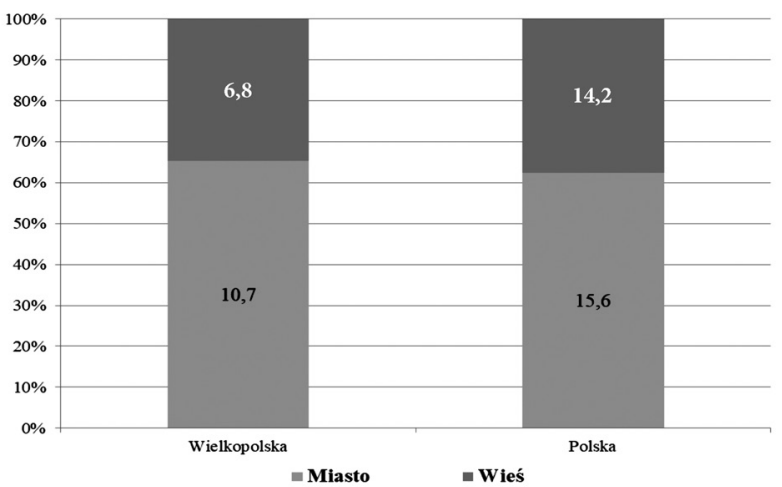

Ryc. 7. Zapadalność na gruźlicę wszystkich postaci w Polsce i Wielkopolsce wg miejsca zamieszkania w roku 2017 (zapadalność na 100 tys. ludności)

W 2017 roku po raz kolejny zapadalność na gruźlicę wśród mieszkańców miast była wyższa w porównaniu z ludnością miejską. W Polsce zarejestrowano 3614 zachorowań w miastach (zapadalność 15,6) oraz 2173 przypadków na wsi (zapadalność 
14,2). W Wielkopolsce zarejestrowano 203 zachorowania w miastach (zapadalność $10,7)$ oraz 108 przypadków na wsi (zapadalność 6,8). Udział procentowy zachorowań w mieście oraz na wsi, zarówno w Polsce jak i Wielkopolsce oscylował w podobnym zakresie (miasto - Polska 62,5\%, Wielkopolska 65,3\%; wieś - Polska 37,5\%, Wielkopolska $34,7 \%)$.

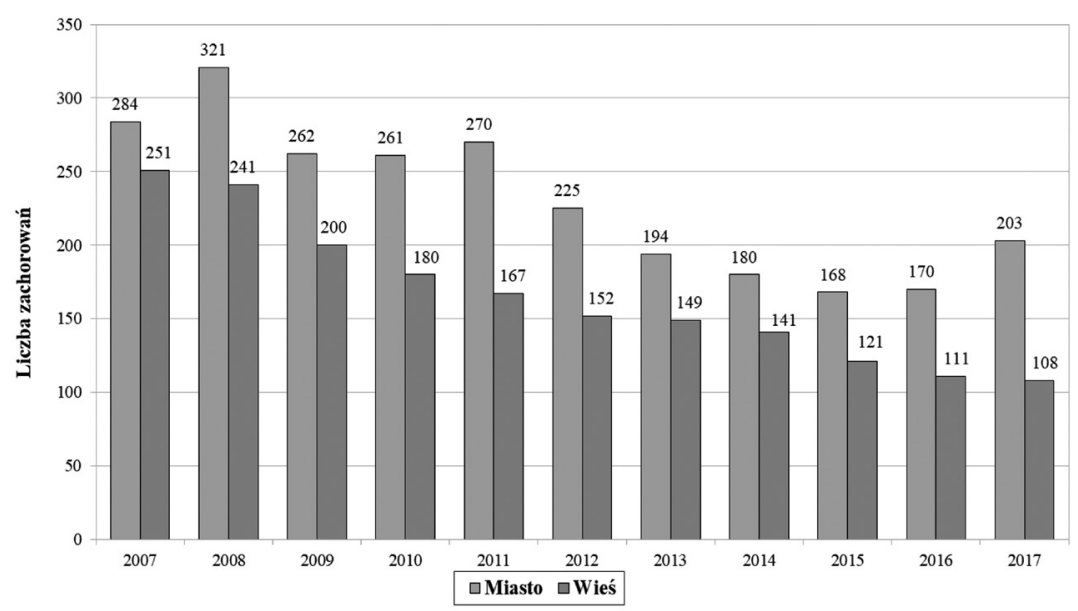

Ryc. 8. Liczba zachorowań na gruźlicę wszystkich postaci wg miejsca zamieszkania w Wielkopolsce w latach 2007-2017 (dane liczbowe)

Liczba zachorowań na gruźlicę w Wielkopolsce wśród mieszkańców miast i wsi od kilkunastu lat ma tendencję spadkowa, przeważają natomiast zachorowania w mieście. Jedynie w $2017 \mathrm{r}$. w porównaniu do roku poprzedniego odnotowano wzrost liczby zachorowań mieszkańców miast o 33 przypadki.

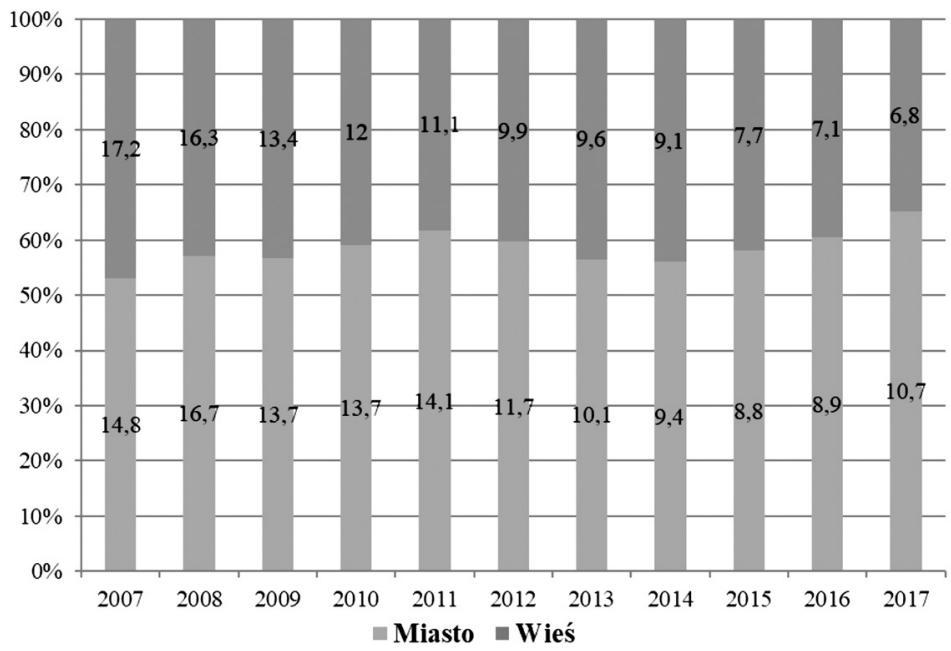

Ryc. 9. Zapadalność na gruźlicę wszystkich postaci wg miejsca zamieszkania w Wielkopolsce w latach 2007-2017 (zapadalność na 100 tys. ludności) 
Zapadalność na gruźlicę w Wielkopolsce wśród mieszkańców wsi na przestrzeni kilkunastu lat rokrocznie spadała. Niewielkie wahania zapadalności w porównaniu do roku poprzedniego odnotowywano natomiast wśród mieszkańców miast. Największy wzrost zapadalności w tej grupie zrejestrowano w roku 2017 - o 20,2\%. Mieszkańcy miast stanowili około $60 \%$ grupę wszystkich rejestrowanych w województwie zachorowań.

Tabela 2. Sytuacja epidemiologiczna gruźlicy - postać płucna i pozapłucna

\begin{tabular}{|c|c|c|c|c|c|c|c|c|}
\hline \multirow{2}{*}{ Lata } & \multicolumn{4}{|c|}{ Gruźlica płucna } & \multicolumn{3}{c|}{ Gruźlica pozapłucna } \\
\cline { 2 - 9 } & \multicolumn{2}{|c|}{ Polska } & \multicolumn{2}{c|}{ Wielkopolska } & \multicolumn{2}{c|}{ Polska } & \multicolumn{2}{c|}{ Wielkopolska } \\
\cline { 2 - 9 } & $\begin{array}{c}\text { Liczba } \\
\text { zachorowań }\end{array}$ & $\%$ & $\begin{array}{c}\text { Liczba } \\
\text { zachorowań }\end{array}$ & $\%$ & $\begin{array}{c}\text { Liczba } \\
\text { zachorowań }\end{array}$ & $\%$ & $\begin{array}{c}\text { Liczba } \\
\text { zachorowań }\end{array}$ & $\%$ \\
\hline 2012 & 7018 & 93,1 & 355 & 94,2 & 524 & 6,9 & 22 & 5,8 \\
\hline 2013 & 6835 & 94,3 & 327 & 95,3 & 415 & 5,7 & 16 & 4,7 \\
\hline 2014 & 6311 & 94,2 & 295 & 91,9 & 387 & 5,8 & 26 & 8,1 \\
\hline 2015 & 6078 & 94,5 & 278 & 96,2 & 352 & 5,5 & 11 & 3,8 \\
\hline 2016 & 6116 & 94,9 & 298 & 96,4 & 328 & 5,1 & 13 & 3,5 \\
\hline 2017 & 5531 & 95,6 & 298 & 95,8 & 256 & 4,4 & 13 & 4,2 \\
\hline
\end{tabular}

W roku 2017, tak samo jak w latach poprzednich w Polsce oraz Wielkopolsce płucna postać gruźlicy stanowiła ponad 95\% zachorowań. W Polsce zarejestrowano o 72 przypadki mniej postaci pozapłucnej gruźlicy, w województwie wielkopolskim liczba zachorowań tej postaci była taka sama jak w roku 2016.

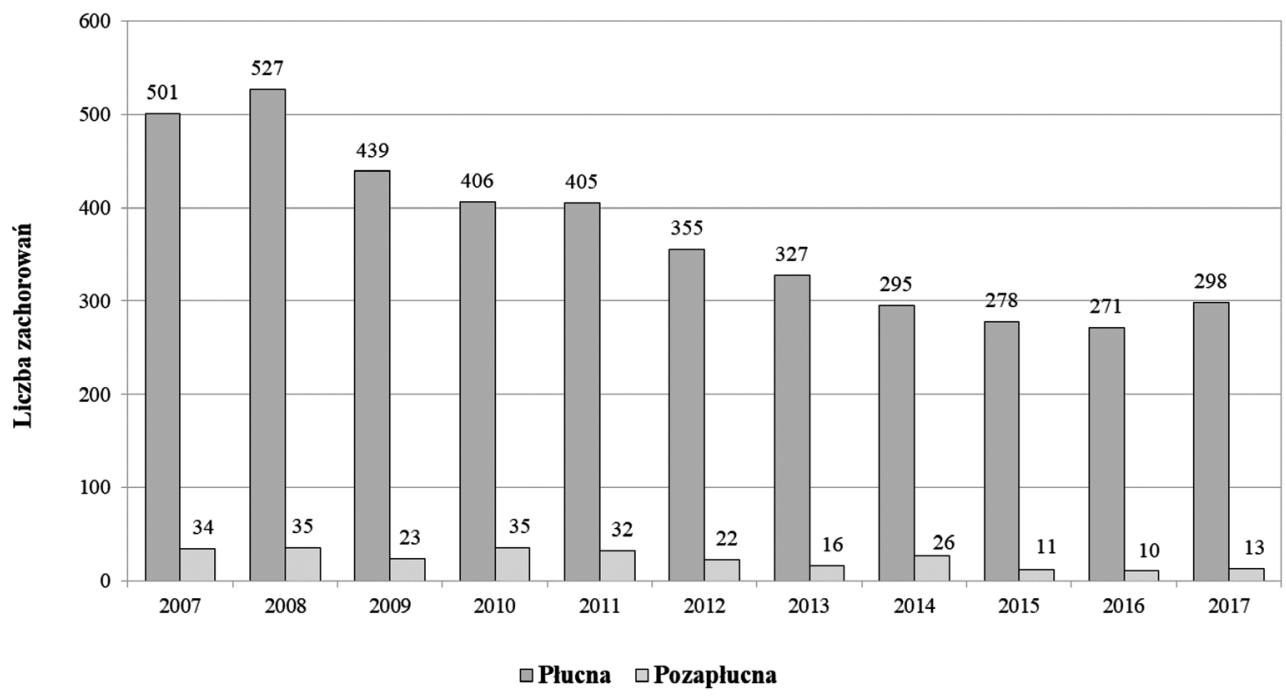

Ryc. 10. Liczba zachorowań na gruźlicę płucną oraz pozapłucną w Wielkopolsce w latach 2007-2017 (dane liczbowe) 
Liczba zachorowań na płucną oraz pozapłacana postać gruźlicy w Wielkopolsce od kilkunastu lat ma tendencję spadkowa. Jedynie w 2017 r. w porównaniu do roku poprzedniego odnotowano wzrost liczby przypadków gruźlicy płucnej - o 27 zachorowania. Tak jak w Polsce, zachorowania na gruźlice płucną w województwie wielkopolskim stanowią większość ogółu zachorowań.

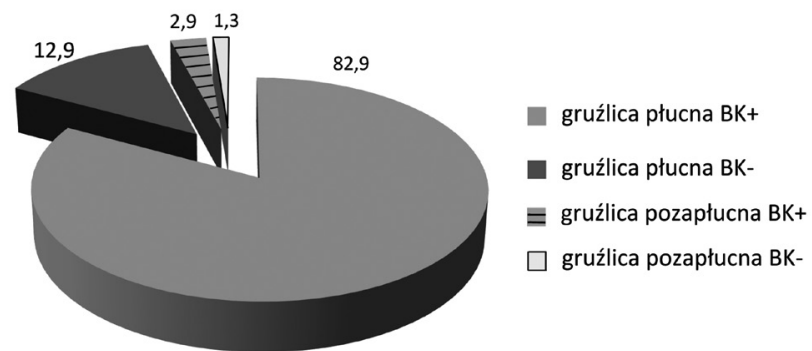

Ryc. 11. Udział procentowy wszystkich postaci gruźlicy wg lokalizacji i stanu bakteriologicznego w województwie wielkopolskim w roku 2017. Udział procentowy według ogółu zachorowań

W 2017 roku w województwie wielkopolskim gruźlica została potwierdzona badaniami bakteriologicznymi u 267 chorych, w tym w 258 przypadkach gruźlicy płuc. Chorzy z potwierdzeniem bakteriologicznym stanowili 85,9\% ogółu chorych. Wśród chorych na gruźlicę płuc odsetek ten wynosił $86,6 \%$. W grupie 13 chorych na gruźlicę pozapłucną rozpoznanie potwierdzono bakteriologicznie u 9 osób.

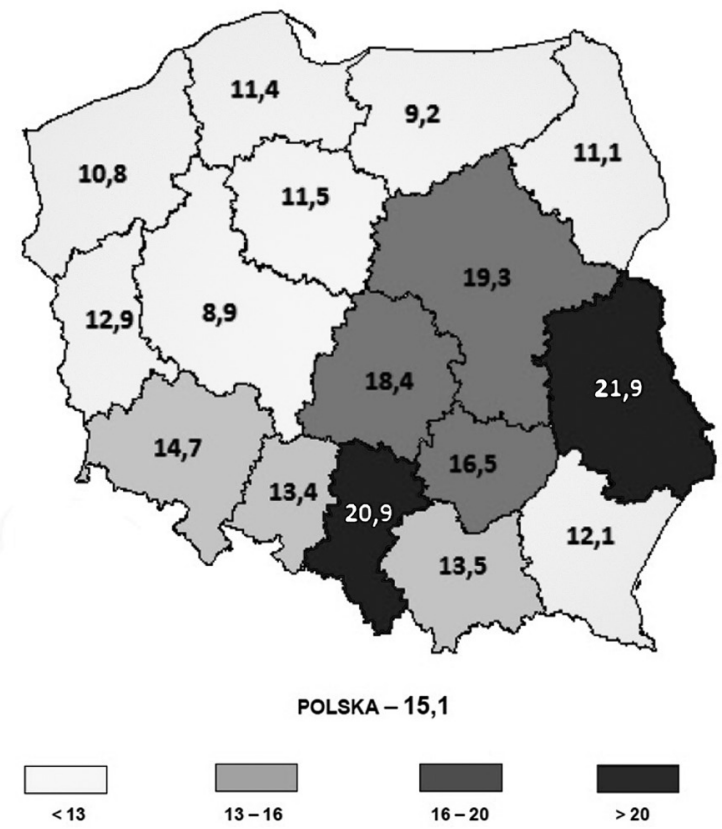

Ryc. 12. Zapadalność na gruźlicę w Polsce w 2017 roku wg województw 
Znaczne różnice współczynników zapadalności na gruźlicę miedzy województwami, obserwowane od lat, wystapiły także w 2017 r. Największą zapadalność na gruźlicę wszystkich postaci zarejestrowano w województwach: lubelskim - 21,9; śląskim - 20,09; mazowieckim - 19,3 i łódzkim - 18,4. W województwach: wielkopolskim - 8,9; warmińsko-mazurskim - 9,2; zachodnio-pomorskim - 10,8 i podlaskim -11,1 współczynniki zapadalności na gruźlicę wszystkich postaci były najniższe w całym kraju. W 2017 roku spadek zapadalności na gruźlicę wszystkich postaci w porównaniu z rokiem poprzedni wystapił w 12 województwach. Współczynniki zapadalności wyższe niż w roku 2016 stwierdzono w woj. wielkopolskim (8,9 vs. 8,1); podlaskim (11,1 vs. 10,2); lubelskim (21,9 vs. 20,8$)$ i lubuskim (12,9 vs. 12,8$)$. Województwo wielkopolskie w sposób bardzo korzystny przedstawia się na epidemiologicznej mapie gruźlicy w Polsce.

Tabela 3. Ranking województw wg zapadalności na gruźlicę wszystkich postaci w Polsce w 2017 roku

\begin{tabular}{|c|c|}
\hline Ranking województw & Współczynnik \\
\hline \multicolumn{2}{|c|}{ POLSKA 15,1 } \\
\hline 1. Wielkopolskie & 8,9 \\
\hline 2. Warmińsko-mazurskie & 9,2 \\
\hline 3. Zachodnio-pomorskie & 10,8 \\
\hline 4. Podlaskie & 11,1 \\
\hline 5. Pomorskie & 11,4 \\
\hline 6. Kujawsko-pomorskie & 11,5 \\
\hline 7. Podkarpackie & 12,1 \\
\hline 8. Lubuskie & 12,9 \\
\hline 9. Opolskie & 13,4 \\
\hline 10. Małopolskie & 13,5 \\
\hline 11. Dolnośląskie & 14,7 \\
\hline 12. Świętokrzyskie & 16,5 \\
\hline 13. Łódzkie & 18,4 \\
\hline 14. Mazowieckie & 19,3 \\
\hline 15. Śląskie & 20,9 \\
\hline 16. Lubelskie & 21,9 \\
\hline
\end{tabular}

Zapadalność na 100 tys. ludności

Województwo wielkopolskie w sposób bardzo korzystny klasyfikuje się w ranking województw wg zapadalności na gruźlicę wszystkich postaci w Polsce w 2017 r. Jest województwem o najniższym współczynniku zapadalności. 
Tabela 4. Ranking województwa wielkopolskiego wg zapadalności na gruźlicę wszystkich postaci w Polsce w latach 2007-2017 roku

\begin{tabular}{|c|c|c|c|c|c|}
\hline Rok & $\begin{array}{c}\text { Średni } \\
\text { współczynnik } \\
\text { zapadalności } \\
\text { w Polsce }\end{array}$ & $\begin{array}{c}\text { Współczynnik } \\
\text { zapadalności } \\
\text { w Wielkopolsce }\end{array}$ & $\begin{array}{c}\text { Miejsce } \\
\text { Wielkopolski } \\
\text { w rankingu } \\
\text { województw }\end{array}$ & $\begin{array}{c}\text { Województwo } \\
\text { o najmniejszym } \\
\text { współczynniku } \\
\text { zapadalności }\end{array}$ & $\begin{array}{c}\text { Najmniejszy } \\
\text { współczynnik } \\
\text { zapadalnó́ci } \\
\text { w Polsce }\end{array}$ \\
\hline 2007 & 22,7 & 15,8 & 3 & Lubuskie & 11,5 \\
\hline 2008 & 21,2 & 16,6 & 2 & Lubuskie & 12,0 \\
\hline 2009 & 21,6 & 13,6 & 1 & Wielkopolskie & 13,6 \\
\hline 2010 & 19,7 & 12,9 & 2 & Opolskie & 12,8 \\
\hline 2011 & 22,2 & 12,8 & 1 & Wielkopolskie & 12,8 \\
\hline 2012 & 19,6 & 10,6 & 2 & Lubuskie & 10,6 \\
\hline 2013 & 18,8 & 9,9 & 1 & Wielkopolskie & 9,9 \\
\hline 2014 & 17,4 & 9,3 & 1 & Wielkopolskie & 9,3 \\
\hline 2015 & 16,7 & 8,3 & 1 & Wielkopolskie & 8,3 \\
\hline 2016 & 16,8 & 8,1 & 1 & Wielkopolskie & 8,1 \\
\hline 2017 & 15,1 & 8,9 & 1 & Wielkopolskie & 8,9 \\
\hline
\end{tabular}

Zapadalność na 100 tys. ludności

Od pięciu lat województwo wielkopolskie jest regionem o najniższym współczynniku zapadalności. Jednocyfrowy współczynnik powala porównywać region do państw o najlepszej sytuacji epidemiologicznej w zakresie gruźlicy.

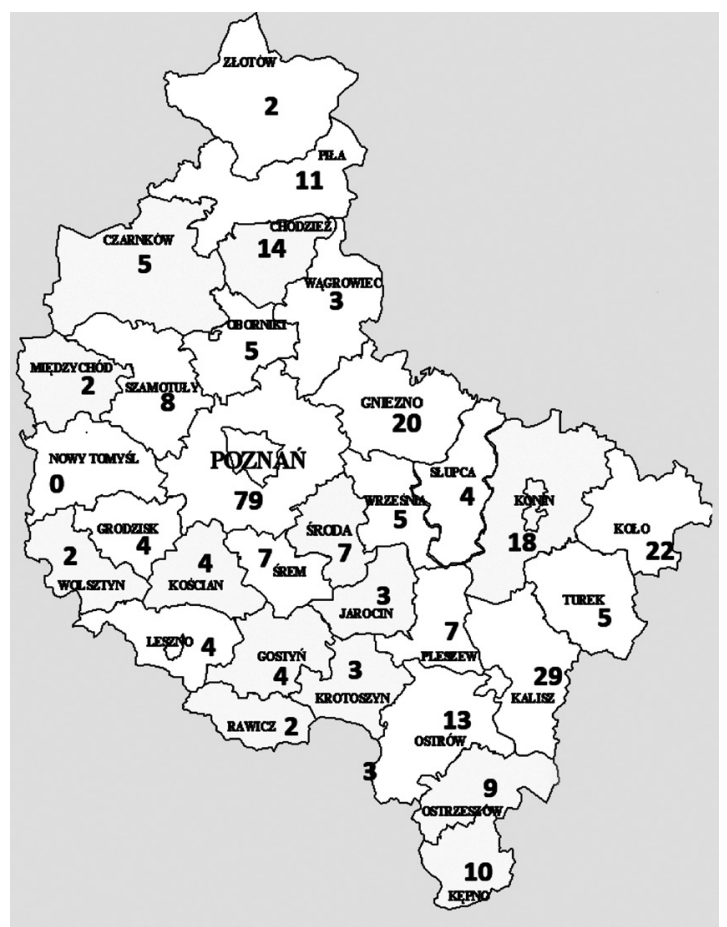

Ryc. 13. Liczba zachorowań na gruźlicę w powiatach województwa wielkopolskiego w 2017 r. 


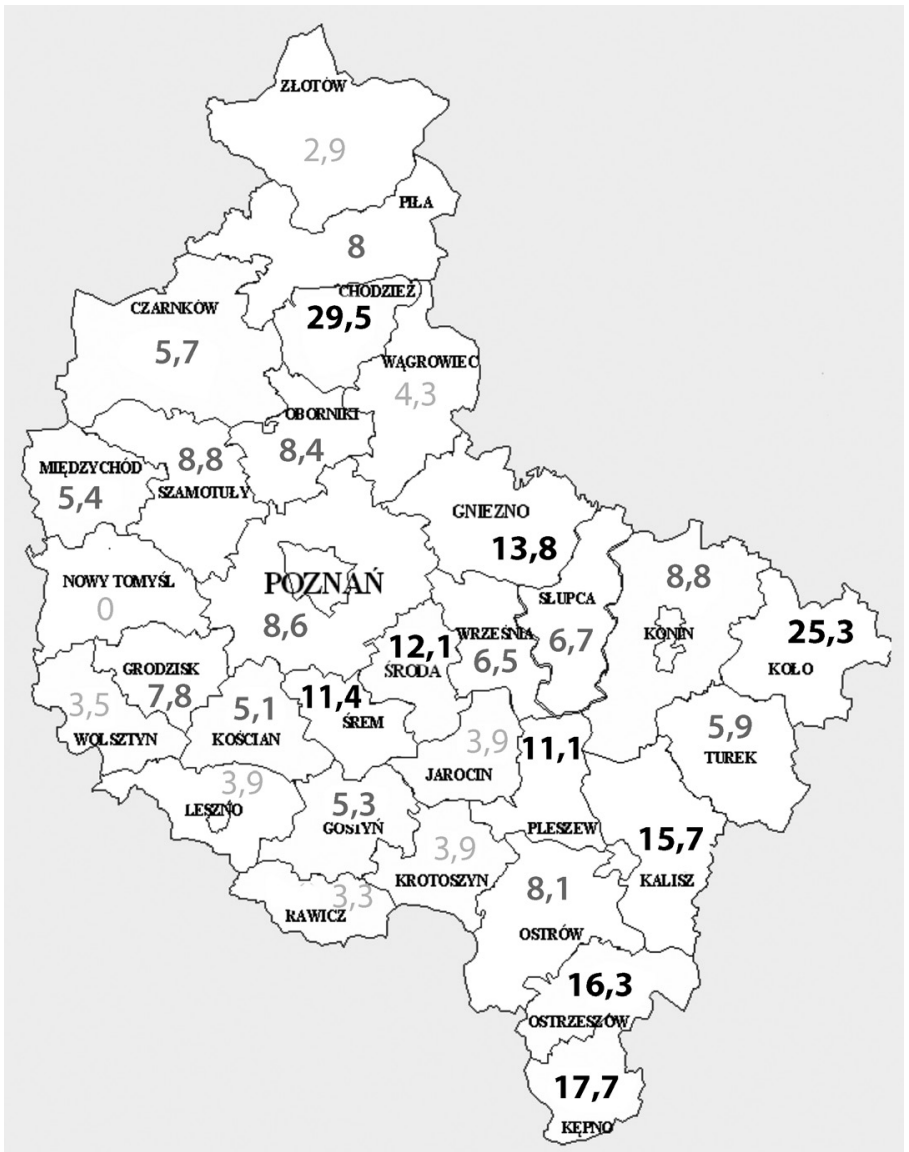

Ryc. 14. Zapadalność na gruźlicę w powiatach województwa wielkopolskiego w 2017 r. (zapadalność na 100 tys. ludności)

8,9 - średnia zapadalność w woj. wielkopolskim

zapadalność powyżej średniej zapadalności w woj. Wielkopolskim (zakres powyżej 8,9)

zapadalność poniżej średniej zapadalności w woj. wielkopolskim (zakres 5-8,9)

najniższa zapadalności w woj. Wielkopolskim (zakres poniżej 5)

\section{System nadzoru nad gruźlicą w województwie wielkopolskim}

Nadzór nad gruźlica na poziomie powiatowych stacji sanitarno-epidemiologicznych województwa wielkopolskiego.

- Weryfikacja otrzymanych formularzy podejrzeń, zachorowań na gruźlice oraz dodatnich wyników badań laboratoryjnych w kierunku gruźlicy. 
- Przeprowadzanie wywiadów epidemiologicznych przez pracowników PSSE lub pielęgniarki środowiskowe (PSSE Poznań) w środowisku chorego na prątkująca postać gruźlicy płucnej (na opracowanym przez WSSE formularzu).

- Sporzadzanie wykazu osób z bezpośredniej styczności z chorym na pratkująca postać gruźlicy płucnej BK+ (zgodnie z definicja zakaźności pacjenta).

- Ustalanie lekarza rodzinnego sprawującego opiekę nad poszczególnymi osobami z kontaktu.

- Poinformowanie osób z kontaktu o konieczności zgłoszenia się do lekarza rodzinnego.

- Przekazanie informacji (w formie pisemnej) o konieczności objęcia nadzorem osób ze styczności z chorym na gruźlice do lekarzy rodzinnych.

- Uzyskanie informacji czy osoba z kontaktu została objęta opieka medyczna przez lekarza rodzinnego oraz czy została skierowana do poradni pulmonologicznej.

- Uzyskanie informacji czy osoba z kontaktu zgłosiła się do poradni pulmonologicznej.

- W przypadku niezgłoszenia się osoby z kontaktu do lekarza POZ lub specjalisty podejmowanie działań wyjaśniających.

- Wydawanie decyzji administracyjnych i ich egzekwowanie.

- Przekazywanie do PWIS formularzy zgłoszeń zachorowania na gruźlice oraz wyników laboratoryjnych potwierdzających zakażenie.

- Po zakończonym dochodzeniu epidemiologicznym przesyłanie do PWIS kompletnie wypełnionych formularzy wywiadów wraz z wykazem osób z kontaktu objętych nadzorem.

Nadzór nad gruźlicą na poziomie Wojewódzkiej Stacji Sanitarno-Epidemiologicznej w Poznaniu.

- Weryfikacja otrzymanych z PSSE formularzy zgłoszeń podejrzeń, zachorowań na gruźlice oraz zgłoszeń dodatnich wyników laboratoryjnych.

Prowadzenie rejestrów:

- Wojewódzki Rejestr Zachorowań na Gruźlicę

(Rejestr prowadzony na podstawie formularzy zgłoszeń zachorowań na gruźlicę)

- Wojewódzki Rejestr Dodatnich Wyników Badań Laboratoryjnych Biologicznego Czynnika Chorobotwórczego Mycobacterium tuberculosis complex

(Rejestr prowadzony na podstawie formularzy zgłoszeń dodatniego wyniku badania laboratoryjnego potwierdzającego zakażenie gruźlicą)

- Weryfikacja otrzymanych formularzy zgłoszeń zgonów/podejrzeń zgonów z powodu gruźlicy.

- Prowadzenie Wojewódzkiego Rejestru Zgonów

(Rejestr prowadzony na podstawie formularzy zgłoszeń zgonów/podejrzeń zgonów z powodu choroby zakaźnej) 


\section{SYSTEM OPIEKI ZDROWOTNEJ}

(kryteria rozpoznania gruźlicy)

SZPITALE, PLACÓWKI POZ, TERENOWE PORADNIE CHORÓB PLUC I GRUŹLICY

- objawy kliniczne i/lub zmiany radiologiczne odpowiadające gruźlicy

- chorzy prątkujący lub z uzasadnionym podejrzeniem prątkowania

- włączone leczenie przeciwprątkowe

\section{7

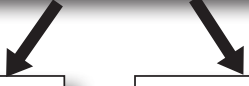

- bakterioskopia - wykazanie prątków kwasoopornych w rozmazie bezpośrednim

- hodowla - izolacja prątków z grupy Mycobacterium tuberculosis complex

- włączone leczenie przeciwprątkowe

\section{PRZESYŁANIE FORMULARZA} ZGŁOSZENIA ZACHOROWANIA (podejrzenie zachorowania na gruźlicę)

Państwowy Powiatowy Inspektor Sanitarny właściwy dla miejsca rozpoznania zakażenia lub choroby zakaźnej

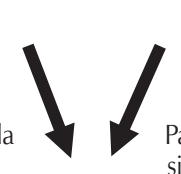

PRZESYŁANIE FORMULARZA DODATNIEGO WYNIKU BADANIA BAKTERIOLOGICZNEGO

Państwowy Powiatowy Inspektor Sanitarny właściwy dla siedziby laboratorium, w którym rozpoznano zakażenie

\footnotetext{
PAŃSTWOWY POWIATOWY INSPEKTOR SANITARNY
PAŃSTWOWY POWIATOWY INSPEKTOR SANITARNY

(właściwy ze względu na miejsce zachorowania = zamieszkania)

- $\quad$ współpraca z jednostkami wykrywającymi i leczącymi gruźlicę:

- $\quad$ weryfikacja zgłoszonych rozpoznań gruźlicy oraz podejrzeń gruźlicy,

- $\quad$ otrzymywanie z poradni p/gruźliczych znajdujących się na terenie powiatu kwartalnych wykazów osób zarejestrowanych na gruźlicę,

- $\quad$ nadzór nad osobami z kontaktu z chorymi na gruźlicę płucną BK+,

- przesyłanie do WPWIS:

- $\quad$ kompletnie wypełnionych formularzy zgłoszeń zachorowań, po zakończonym diagnozowaniu gruźlicy (formularze muszą zawierać dane o wynikach bakterioskopii i posiewu),

- formularzy dodatnich wyników badania laboratoryjnego,

- formularzy wywiadów epidemiologicznych o zachowaniu na prątkującą postać gruźlicy płucnej,

- $\quad$ kwartalnych wykazów osób chorych na gruźlicę zarejestrowanych w poradniach p/gruźliczych.
}

\section{I}

\section{WIELKOPOLSKI PAŃSTWOWY WOJEWÓDZKI INSPEKTOR SANITARNY}

- $\quad$ współpraca z jednostkami wykrywającymi i leczącymi gruźlicę:

- $\quad$ weryfikacja otrzymanych formularzy zgłoszenia zachorowania na gruźlicę,

- rejestracja zachorowań

Wojewódzki Rejestr Zachorowań na Gruźlicę

- $\quad$ rejestracji jako zachorowania podlegają nowe zachorowania i wznowy rozpoznane jako gruźlica (nie podejrzenia) z włączonym pełnym leczeniem przeciwprątkowym,

- rejestracja dodatnich wyników badania laboratoryjnego

Wojewódzki Rejestr Dodatnich Wyników Badań Laboratoryjnych Biologicznego Czynnika

Chorobotwórczego Mycobacterium tuberculosis complex

- przesyłanie do Instytutu Gruźlicy i Chorób Płuc w Warszawie:

- formularzy zgłoszeń zachorowań,

- $\quad$ wykazu osób chorych na gruźlicę zarejestrowanych w poradniach p/gruźliczych województwa wielkopolskiego

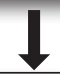

INSTYTUTU GRUŹLICY I CHORÓB PLUC W WARSZAWIE

Krajowy Rejestr Zachorowań na Gruźlicę

Ryc. 15. Schemat postępowania w nadzorze nad gruźlicą w zakresie diagnozowania,

rejestracji i profilaktyki w województwie wielkopolskim 


\section{Nadzór nad osobami o wysokim ryzyku zachorowania na gruźlicę}

W przypadku ustalenia $\mathrm{w}$ trakcie dochodzenia epidemiologicznego osób z kontaktu z chorym, które zaliczają się do grupy o wysokim ryzyku zachorowania, należy objać ich szczególnym nadzorem.

\section{Osoby o wysokim ryzyku zachorowania:}

a) Osoby z objawami gruźlicy;

U osób z kontaktu z objawami gruźlicy wykonywane są badania RTG oraz badania bakteriologiczne (postępowanie lekarskie tak jak przy podejrzeniu czynnej gruźlicy);

b) Osoby w stanie immunosupresji oraz dzieci poniżej 5 lat;

Osoby takie powinny zostać jak najszybciej skierowane do lekarza. Należy wykonać badania w trybie pilnym, zaleca się przeprowadzenie pierwszych badań w ciagu tygodnia od wykrycia przypadku wskaźnikowego.

\section{Badania osób w stanie immunosupresji oraz dzieci poniżej 5 lat}

- Pierwsze badanie do tygodnia od wykrycia przypadku wskaźnikowego:

- badanie kliniczne,

- test IGRA (ewentualnie próba tuberkulinowa gdy nie ma możliwości wykonania testu),

- Rtg płuc.

Rekomendowane jest włączenie chemioprofilaktyki po wykluczeniu aktywnej gruźlicy.

- Drugie badanie po 8 tygodniach od dnia pierwszego badania:

Osoby w stanie immunosupresji oraz dzieci poniżej 6 miesiąca życia:

- Rtg płuc,

- test IGRA,

- zalecana jest kontynuacja leczenia profilaktycznego (nawet gdy wyniki sa ujemne).

Dzieci powyżej 6 miesiąca do 5 roku życia

- Rtg płuc,

- test IGRA,

- leczenie profilaktyczne może być wstrzymane jeżeli wynik testu IGRA jest ujemny.

\section{Badania dzieci od 5 roku życia do lat 16}

Badanie lekarskie oraz po 8 tygodniach od ostatniego kontaktu z chorym wykonanie testu IGRA (ewentualnie próba tuberkulinowa gdy nie ma możliwości wykonania testu).

Wynik testu dodatni

- Rtg płuc

- po wykluczeniu aktywnej gruźlicy rekomendowane jest włączenie leczenia profilaktycznego
Wynik testu ujemny

- lekarz może zalecić Rtg płuc 


\section{Osoby powyżej 16 roku życia}

Badanie lekarskie oraz po 8 tygodniach od ostatniej ekspozycji wykonanie testu IGRA (ewentualnie próba tuberkulinowa gdy nie ma możliwości wykonania testu).

Wynik testu dodatni

- Rtg płuc

- u osób pomiędzy 16 i 35 rokiem życia należy rozważyć leczenia profilaktyczne

- u osób powyżej 35 roku życia bez zaburzeń odporności zaleca się jedynie obserwację
Wynik testu ujemny

- lekarz może zalecić Rtg płuc

Ryzyko rozwoju gruźlicy jest największe w ciagu dwóch lat od zakażenia. U osób z kontaktu nieleczonych farmakologicznie można przez 2 lata wykonywać badania radiologicznie corocznie lub nawet 2 razy do roku.

\section{Podsumowanie}

Aktualny poziom zapadalności na gruźlicę w Polsce pozwala zaliczyć nasz kraj do krajów o niskiej zapadalności. Polska jest przykładem kraju, który dzięki właściwie prowadzonemu nadzorowi epidemiologicznemu, sprawnym programom prewencyjnym, dobrze zorganizowanej sieci specjalistycznych poradni przeciwgruźliczych i oddziałów szpitalnych specjalizujących się w diagnostyce i leczeniu gruźlicy oraz sieci działających laboratoriów mikrobiologicznych, poczynił ogromny postęp w nadzorze nad gruźlicą skutkujacym poprawą sytuacji epidemiologicznej.

Wykaz literatury:

1. Ustawa o zapobieganiu oraz zwalczaniu zakażeń i chorób zakaźnych u ludzi z dnia 5 grudnia $2008 \mathrm{r}$. (Dz.U. z 2018 r. poz. 151).

2. Gruźlica i choroby układu oddechowego w Polsce w 2017 r., red. Maria Korzeniewska-Koseła. Instytut Grúzlicy i Chorób Płuc, Warszawa 2018.

3. Informacje ogólne i praktyczne wskazówki do programu wczesnego wykrywania gruźlicy w województwie wielkopolskim. Wielkopolskie Centrum Pulmonologii i Torakochirurgii, Poznań 2017. 